Division of Geological \& Geophysical Surveys

\title{
GEOPHYSICAL REPORT 2003_4
}

\section{PORTFOLIO OF AEROMAGNETIC AND RESISTIVITY MAPS OF THE COUNCIL AREA, SEWARD PENINSULA, ALASKA}

\author{
by \\ Laurel E. Burns \& Karen H. Clautice
}

February 2003

THIS REPORT HAS NOT BEEN REVIEWED FOR TECHNICAL CONTENT (EXCEPT AS NOTED IN TEXT) OR FOR CONFORMITY TO THE EDITORIAL STANDARDS OF DGGS.

Released by

STATE OF ALASKA DEPARTMENT OF NATURAL RESOURCES

Division of Geological \& Geophysical Surveys

794 University Avenue, Suite 200

Fairbanks, Alaska 99709-3645 


\section{PORTFOLIO OF AEROMAGNETIC AND RESISTIVITY MAPS OF THE COUNCIL AREA, SEWARD PENINSULA, ALASKA}

In the summer of 2002, the Alaska Division of Geologic \& Geophysical Surveys acquired airborne geophysical data over 633 square miles in the Solomon and Bendeleben Quadrangles (figure 1). The data were acquired and processed under contract by Stevens Exploration Management, Corp. and their subcontractor, Fugro Airborne Surveys. Aeromagnetic and electromagnetic data were collected in August of 2002 and were released February 2003 in the forms of maps and digital files.

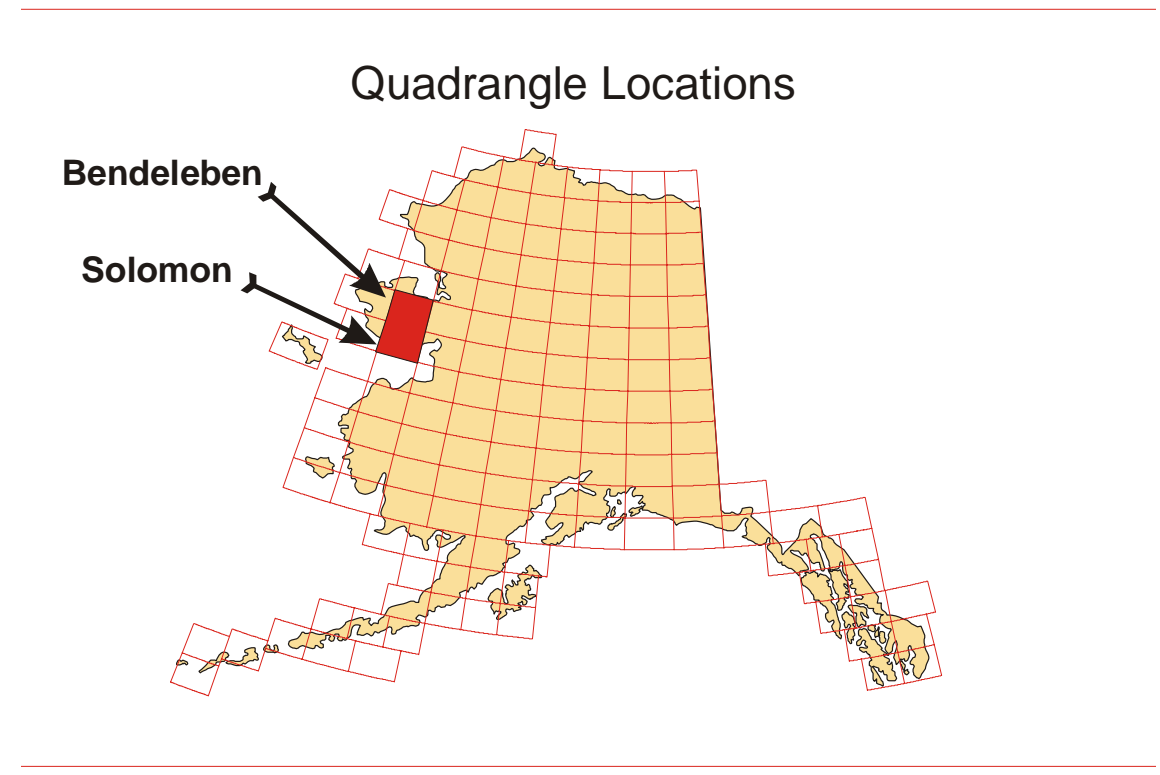

Figure 1. Location of Bendeleben and Solomon Quadrangles.

This Geophysical Report (GPR) contains generalized information on data acquisition, data interpretation, publications, and data formats available for the Council geophysical survey. Page-size color maps of most of the data are also included. The contractor's report, GPR 2003_3, gives a more detailed interpretation of the data and a more complete description of the processing.

The acetate topography included with this portfolio should be used only for generalized locations. For accurate locations, the large-scale geophysical maps or the computer files should be used. The area surveyed in 2002 includes parts of the Solomon C-4, C-5, D-4, and D-5 and Bendeleben A-4 and A-5 Quadrangles.

Clients can request maps from this geophysical survey from the Alaska Division of Geological \& Geophysical Surveys. Ordering information and available maps are listed at the end of this portfolio. Some of the products are available at DNR's Public Information Center in Anchorage. Most of the maps in this portfolio are available from DGGS. Custom plots of variations of the data can be made at any scale at the DGGS office for a reasonable fee.

\section{PRODUCTS AVAILABLE FROM THIS SURVEY}

Maps are available of the aeromagnetic, $7200 \mathrm{~Hz}$ coplanar resistivity data, and $900 \mathrm{~Hz}$ coplanar resistivity data. Most of the maps for the Council area were produced at 1:63,360 scale (1 inch =1 mile, fig. 2). 
Aeromagnetic maps with electromagnetic (EM) anomalies were produced at 1:63,360-scale with simplified EM symbols and 1:31,680-scale $(1$ inch $=1 / 2$ mile; fig. 3$)$ with detailed EM symbols $(1$ inch $=$ $1 / 2$ mile; fig. 3).

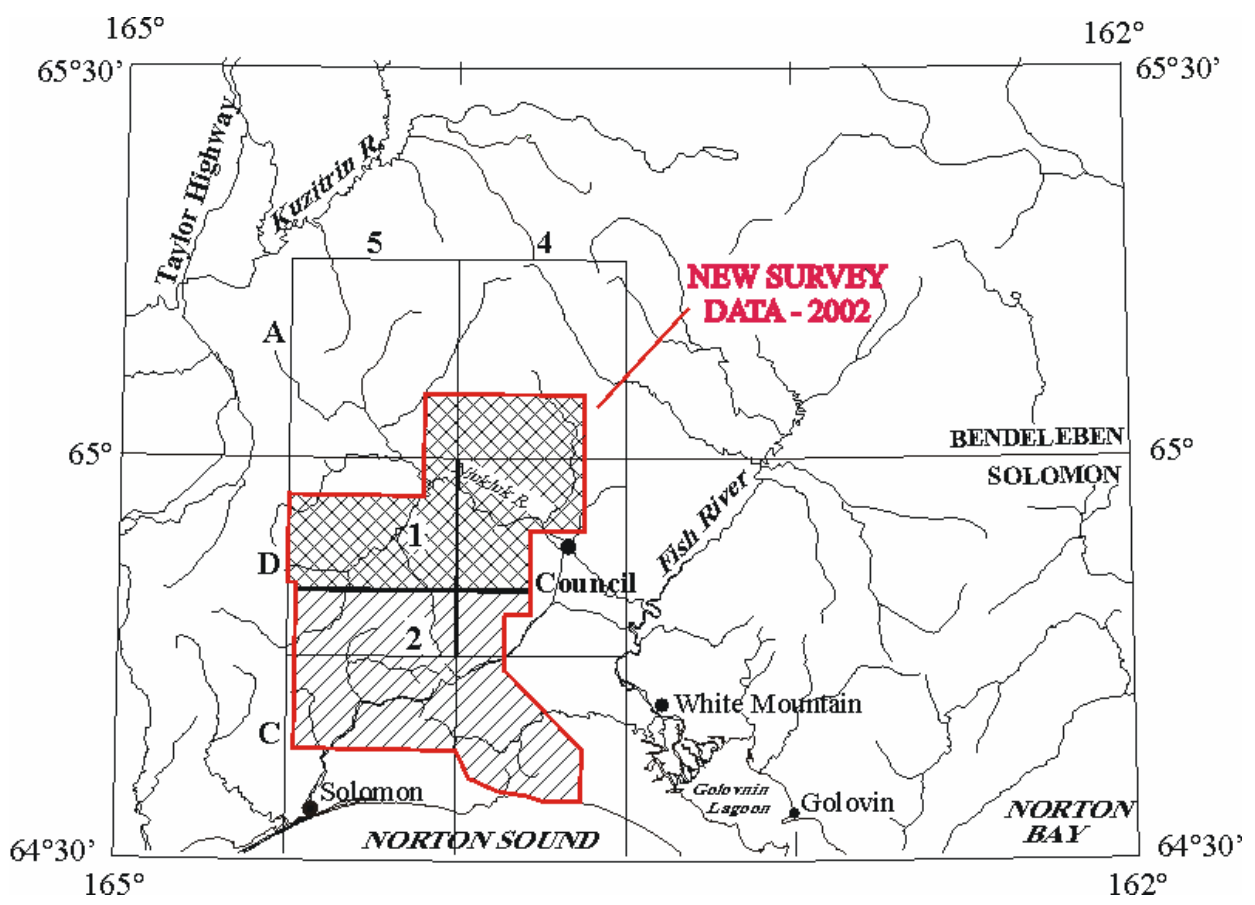

Figure 2. Index map showing area of data acquisition (red outline) superimposed on parts of the Bendeleben and Solomon Quadrangles. All 63,360-scale maps fit on two sheets.

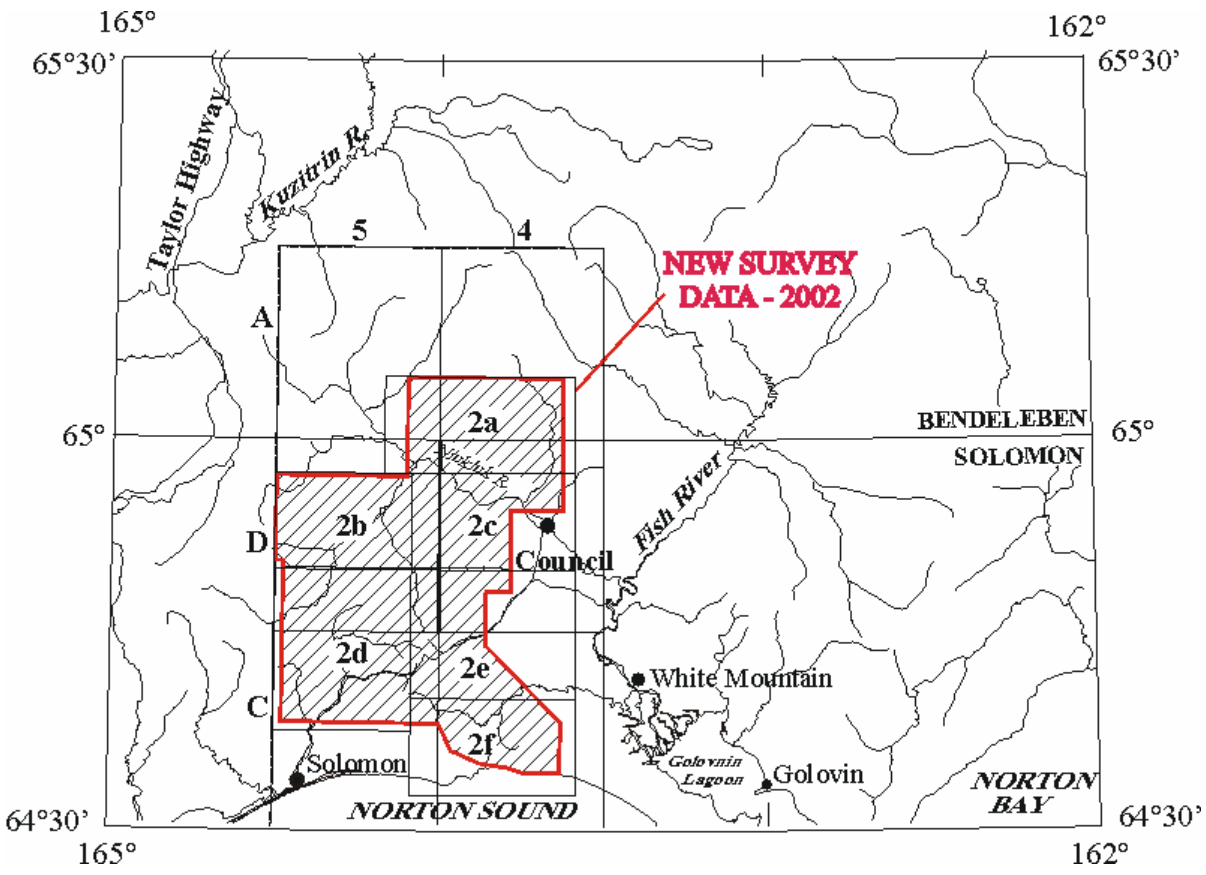

Figure 3. Index map for aeromagnetic maps available at $1: 31,680(1 \mathrm{inch}=1 / 2 \mathrm{mile})$ scale. Only 
aeromagnetic maps with detailed EM anomalies are available at this scale. Six map sheets (marked 2a through $2 \mathrm{f}$ ) are used to cover the area at 31,680-scale.

Data from this survey are available in two CD-ROMS and in paper maps (listed near the end of this publication). The CD-ROM GPR 2003_1 contains the 18 maps produced from this survey in both HPGL/2 format and postscript printer format. The HPGL2 plot files (prn printer file format) were made with an HP Designjet 2500 HPGL/2 printer driver v4.61 and must be plotted on an HP Designjet 2500. The postscript plot files (ps printer file format) were made with an Hewlett Packard Designjet 2500 Postscript 3 printer driver v5.0 and should plot on all Hewlett Packard plotters that can interpret postscript 3 files. GPR 2003_2 contains the processed line data, gridded data (magnetic data, $900 \mathrm{~Hz}, 7200 \mathrm{~Hz}$, and $56,000 \mathrm{~Hz}$ coplanar apparent resistivity data, and a digital terrain model), data contour files, and detailed electromagnetic anomalies. The processed line data is in Geosoft Ascii format, the gridded data are in both Geosoft binary and ER Mapper format, and the vector files are in Autocad version $14 \mathrm{dxf}$ files.

\section{Survey history, instrumentation, \& data processing}

The following indented section describing the instrumentation and processing is modified from the metadata included on the CD-ROMS.

The airborne geophysical data were acquired with a DIGHEM(V) Electromagnetic (EM) system and a Scintrex cesium magnetometer. Both were flown at a height of 100 feet. In addition, the survey recorded data from a radar altimeter, GPS navigation system, $50 / 60 \mathrm{~Hz}$ monitors and video camera. Flights were performed with an AS350B-2 Squirrel helicopter at a mean terrain clearance of 200 feet along NW-SE (340 degrees) survey flight lines with a spacing of one quarter mile. Tie lines were flown perpendicular to the flight lines at intervals of approximately 3 miles.

An Ashtech GG24 NAVSTAR/GLONASS Global Positioning System was used for navigation. The helicopter position was derived every 0.5 seconds using post-flight differential positioning to a relative accuracy of better than $5 \mathrm{~m}$. Flight path positions were projected onto the Clarke 1866 (UTM zone 3) spheroid, 1927 North American datum using a central meridian (CM) of 165 degrees, a north constant of 0 and an east constant of 500,000.

\section{Total Field Magnetics:}

The total magnetic field data were acquired with a sampling interval of 0.1 seconds, and were (1) corrected for diurnal variations by subtraction of the digitally recorded base station magnetic data, (2) leveled to the tie line data, and (3) interpolated onto a regular $100 \mathrm{~m}$ grid using a modified Akima (1970) technique. The regional variation (or IGRF gradient, 2000, updated to August 2002) was removed from the leveled magnetic data. The aeromagnetic data are interpolated onto a regular $100 \mathrm{~m}$ grid using a modified Akima (1970) technique.

\section{Resistivity:}

The EM inphase and quadrature data are drift corrected using base level data collected at high altitude (areas of no signal). Along-line filters are applied to the data to remove spheric spikes. The data are inspected for variations in phase, and a phase correction is applied to the data if necessary. Resistivities are then calculated from the inphase and quadrature data for all frequencies based on a pseudo-layer half-space model. Manual leveling of the inphase and quadrature of each coil pair, based on the resistivity data and comparisons to the data from the other frequencies, is performed. Automated micro-leveling is carried out in areas of low signal. The resistivity data are then interpolated onto a regular $100 \mathrm{~m}$ grid using a modified Akima (1970) technique. The resulting grids are subjected to a $3 \times 3$ hanning filter before contouring and map production.

Akima, H., 1970, A new method of interpolation and smooth curve fitting based on local procedures: 
Journal of the Association of Computing Machinery, v. 17, no. 4, p. 589-602.

Fraser, D.C., 1978, Resistivity mapping with an airborne multicoil electromagnetic system: Geophysics, v. 43, p.144-172.

\section{$\underline{\text { Generalized information about aeromagnetic, electromagnetic, and radiometric data }}$}

\section{Magnetic data}

The magnetometer is a passive instrument that measures the earth's magnetic field in nanoTeslas (nT). Rocks with high magnetic susceptibilities (measured in SI units) locally attenuate or dampen these magnetic signals producing the relative highs and lows. Iron-rich magnetic minerals such as magnetite, ilmenite, and pyrrhotite have the highest magnetic susceptibility. These minerals commonly occur in mafic volcanic rocks (such as basalt), mafic and ultramafic plutonic rocks (such as serpentinite, clinopyroxenite, and gabbro), some skarns, and in some other geologic units. Rocks with low to no iron tend to produce little variation in the magnetic signal. These include silicic volcanic rocks (rhyolites), silicic plutonic rocks (granites), and most sedimentary rocks (for example, limestone, sandstone, and shale). Some iron rich minerals - such as pyrite - are not magnetic and do not produce a magnetic signal.

Different types of ore deposits have different magnetic signatures. A bedrock gold deposit associated with the top of a granitic pluton would likely be an aeromagnetic low, whereas a magnetite-bearing gold skarn would be an aeromagnetic high. A gold deposit hosted by a low-angle (thrust) fault has a different signature than one hosted by a high-angle fault.

Figures $4 \mathrm{a}$ and $4 \mathrm{~b}$ show the aeromagnetic data for the survey area. The high values (in nT) are purple and orange and indicate appreciably magnetic rocks. The low values are the blues and greens. A gradual change in color indicates a gradual change in the magnetic field strength. This can be caused by either a gradual change in magnetic susceptibility of rocks near the surface, the gradual burial of a rock unit of relatively constant magnetic susceptibility, or the introduction of a new unit at depth. Conversely, an abrupt change in color indicates an abrupt change in the magnetic susceptibility. This is caused by juxtaposing two rock units with very different magnetic susceptibilities such as is the case with faults, volcanic dikes, or some mineralized zones. Faults can be inferred on aeromagnetic maps from linear or curvilinear features composed of discontinuous aeromagnetic highs or lows.

Figure $4 \mathrm{~b}$ shows the aeromagnetic data presented as "color shadow" maps where a simulated light source is shown on the three-dimensional data. The higher values appear bright like mountaintops struck by sunlight. The light source can be rotated in a complete circle with $0^{\circ}$ (north) clockwise to $180^{\circ}$ (south) and back to $360^{\circ}$ (north). Shadow maps can enhance structures, such as faults, intrusions, and the trend of stratigraphic layers

\section{Resistivity data}

The electromagnetic (EM) system is an active instrument that measures the resistivity of the rocks below it by sending out electromagnetic signals at different frequencies and recording the signals that are returned from the earth. The high values (measured in ohm-m) are indicative of resistive (low conductivity) rocks, such as quartzite. Low resistivity (high conductivity) values are present for bedrock conductors (water-saturated clays, graphite, concentrations of certain sulfides, some alteration halos), conductive overburden (water-saturated zones), and cultural sources (e.g. powerlines). The main conductive minerals are graphite, most sulfides, (but not sphalerite), and water-saturated clays. Rocks hydrothermally altered to clay minerals also are conductive. Some faults will show up very well on the resistivity maps, because they either offer a conduit for ground water or they separate rocks with markedly different resistivities. 
The EM instrument (bird) contains 5 or more transmitting coils in front and 5 matching (paired) receiver coils in the rear. Three of these pairs are coplanar - the axes of the coils are perpendicular to the long axis of the bird. Two of these pairs are coaxial - the axes of the coils are parallel to the long axis of the bird. These two major geometric configurations, coplanar and coaxial, record different information about the conductivity of the rocks below. Coplanar coils emphasize horizontal and flat lying conductive units. Coaxial coils emphasize vertical to near vertical conductive units.

The coplanar resistivity data are shown in Figures 5-7. The resistivity maps are produced from the EM coplanar coil pairs, and emphasize horizontal or near horizontal units and structures. Since ground penetration correlates inversely with frequency, the $56,000 \mathrm{~Hz}$ reflects very near surface rocks and the $900 \mathrm{~Hz}$ adds the influence of deeper rocks in general. The $7200 \mathrm{~Hz}$ in general reflects rocks between the two extremes. However, the depth of penetration is variable depending on the resistivity of the rocks the signal is passing through.

EM anomalies are shown with both the 1:63,360 and 1:31,680 scale magnetic maps. EM anomalies are derived from the coaxial coil pairs, which emphasize vertically- or near-vertically-dipping "discrete" bedrock conductors. These EM anomalies are shown as circular symbols along flight lines with the aeromagnetic contours. On the 1:63,360 scale maps, anomalies are subdivided into those with 1) a signal strength greater than 50 siemens, 2) a signal strength less than 50 siemens, and 3) weak conductivity associated with an EM magnetite response. Questionable (or possible) anomalies are also noted.

More detailed interpretations for the electromagnetic anomalies are shown on the 1:31,680 scale aeromagnetic maps. In these maps, the EM anomaly is shown as a symbol that denotes more information about signal strength and the anomaly source than on the 1:63,360 maps. Instead of two signal strengths (greater than or less than 50 siemens) shown on the 1:63,360 maps, signal strength on the 1:31,680 maps is broken into seven subdivisions (e.g. 5-10 siemens, 1-5 siemens, etc). In addition, potential sources shown for each symbol include 1) bedrock conductors, 2) narrow bedrock conductors ("thin dike"), 3) conductive covers ("horizontal thin sheet"), 4) combination including broad conductive rock units, deep conductive weathering, and thick conductive cover, 5) edge of broad conductor, and 6) culture. This information is also available on the CD-ROMS. The project report, GPR 2003-3, gives a more detailed discussion of these EM anomalies.

\section{DGGS PUBLICATIONS PRODUCED FOR THE COUNCIL AREA}

Bold font is used below to highlight the differences between the maps.

\section{CD-ROMS}

GPR 2003_1. Plot files of the airborne geophysical survey data of the Council area, Seward Peninsula, Alaska. 1 CD-ROM set. Contains the 18 maps listed below as GPR 2003_1_1a through GPR 2003_1_6a in both HPGL/2 format and postscript printer format. The HPGL2 plot files (prn printer file format) were made with an HP Designjet $2500 \mathrm{HPGL} / 2$ printer driver v4.61 and must be plotted on an HP Designjet 2500. The postscript plot files (ps printer file format) were made with an Hewlett Packard Designjet 2500 Postscript 3 printer driver v5.0 and should plot on all Hewlett Packard plotters that can interpret postscript 3 files. Note: The HPGL2 plot files have more vivid color than the Postscript files.

GPR 2003_2. Line, gridded, and vector data of airborne geophysical survey data for the Council area, 
Seward Peninsula, Alaska. 1 CD-ROM set. Line data in ASCII format; gridded data in Geosoft and ER Mapper format; vector files in Autocad 14 dxf files.

\section{AEROMAGNETIC MAPS}

GPR 2003_1_1a. Total magnetic field of the Council area, Seward Peninsula, Alaska, 2 sheets, scale 1:63,360. Topography included. Full-color plot from electronic file, 600 dpi.

GPR 2003_1_1b. Total magnetic field of the Council area, Seward Peninsula, Alaska, 2 sheets, scale 1:63,360. Magnetic contours and section lines included. Full-color plot from electronic file, 600 dpi.

GPR 2003_1_1c. Color shadow magnetic map of the Council area, Seward Peninsula, Alaska, 2 sheets, scale 1:63,360. Full-color plot from electronic file, $600 \mathrm{dpi}$.

GPR 2003_1_1d. Total magnetic field and electromagnetic anomalies of the Council area, Seward Peninsula, Alaska, 2 sheets, scale 1:63,360. Magnetic contours, simplified electromagnetic anomalies, and section lines included. Black and white plot from electronic file, $600 \mathrm{dpi}$.

GPR 2003_1_2a. Total magnetic field and detailed electromagnetic anomalies of the Council area, Seward Peninsula, Alaska, 1 sheet, scale 1:31,680 (parts of Bendeleben A-4 and A-5 and Solomon D-4 and D-5 Quadrangles). Magnetic contours, detailed electromagnetic anomalies, and topography included. Black and white plot from electronic file, 600 dpi.

GPR 2003_1_2b. Total magnetic field and detailed electromagnetic anomalies of the Council area, Seward Peninsula, Alaska, 1 sheet, scale 1:31,680 (parts of Solomon D-5 Quadrangle). Magnetic contours, detailed electromagnetic anomalies, and topography included. Black and white plot from electronic file, $600 \mathrm{dpi}$.

GPR 2003_1_2c. Total magnetic field and detailed electromagnetic anomalies of the Council area, Seward Peninsula, Alaska, 1 sheet, scale 1:31,680 (parts of Solomon D-4 and D-5 Quadrangles). Magnetic contours, detailed electromagnetic anomalies, and topography included. Black and white plot from electronic file, $600 \mathrm{dpi}$.

GPR 2003_1_2d. Total magnetic field and detailed electromagnetic anomalies of the Council area, Seward Peninsula, Alaska, 1 sheet, scale 1:31,680 (parts of Solomon C-5 and D-5 Quadrangles). Magnetic contours, detailed electromagnetic anomalies, and topography included. Black and white plot from electronic file, $600 \mathrm{dpi}$.

GPR 2003_1_2e. Total magnetic field and detailed electromagnetic anomalies of the Council area, Seward Peninsula, Alaska, 1 sheet, scale 1:31,680 (parts of Solomon C-4, C-5, D-4 and D-5 Quadrangles). Magnetic contours, detailed electromagnetic anomalies, and topography included. Black and white plot from electronic file, $600 \mathrm{dpi}$.

GPR 2003_1_2f. Total magnetic field and detailed electromagnetic anomalies of the Council area, Seward Peninsula, Alaska, 1 sheet, scale 1:31,680 (parts of Solomon C-4 and C-5 Quadrangles). Magnetic contours, detailed electromagnetic anomalies, and topography included. Black and white plot from electronic file, $600 \mathrm{dpi}$.

\section{RESISTIVITY MAPS}

GPR 2003_1_3a. 7200 Hz coplanar resistivity of the Council area, Seward Peninsula, Alaska, 2 sheets, scale 1:63,360. Topography included. Full-color plot from electronic file, 600 dpi. 
GPR 2003_1_3b. $7200 \mathrm{~Hz}$ coplanar resistivity of the Council area, Seward Peninsula, Alaska, 2 sheets, scale 1:63,360. Resistivity contours and section lines included. Full-color plot from electronic file, 600 dpi.

GPR 2003_1_3c. $7200 \mathrm{~Hz}$ coplanar resistivity of the Council area, Seward Peninsula, Alaska, 2 sheets, scale 1:63,360. Resistivity contours and section lines included. Black and white plot from electronic file, 600 dpi

GPR 2003_1_4a. 900 Hz coplanar resistivity of the Council area, Seward Peninsula, Alaska, 2 sheets, scale 1:63,360. Topography included. Full-color plot from electronic file, 600 dpi.

GPR 2003_1_4b. 900 Hz coplanar resistivity of the Council area, Seward Peninsula, Alaska, 2 sheets, scale 1:63,360. Resistivity contours and section lines included. Full-color plot from electronic file, 600 dpi.

GPR 2003_1_4c. 900 Hz coplanar resistivity of the Council area, Seward Peninsula, Alaska, 2 sheets, scale 1:63,360. Resistivity contours and section lines included. Black and white plot from electronic file, $600 \mathrm{dpi}$.

\section{PROJECT REPORT, PORTFOLIO, FLIGHT LINES, AND DEM}

GPR 2003_1_5a. Flight lines of the Council area, Seward Peninsula, Alaska, 2 sheets, scale 1:63,360. Topography included. Black and white plot from electronic file, $600 \mathrm{dpi}$.

GPR 2003_1_6a. Digital elevation model of the Council area, Seward Peninsula, Alaska, 2 sheets, scale 1:63,360. Produced from survey altimetry. Color plot from electronic file, $600 \mathrm{dpi}$.

GPR 2003_3. Project report of the airborne geophysical survey of the Council area, Seward Peninsula, Alaska, by Ruth Pritchard, Fugro Airborne Surveys, 2003, scale 1:63,360.

GPR 2003_4. Portfolio of aeromagnetic and resistivity maps of the Council area, Seward Peninsula, Alaska. Includes color and shadow maps. Maps fit 81/2” x 11" sheet.

\section{SELECTED REFERENCES FOR THE COUNCIL AREA}

Online links current at the time of this publication are provided when known. DGGS data on the web is either in PDF format (reports) or Mr. SID format (maps).

\section{GEOPHYSICAL DATA}

Alaska Geologic Survey, 1973, Aeromagnetic map, Bendeleben Quadrangle: Alaska Division of Geological \& Geophysical Surveys AOF 3, 2 p., 1 sheet, scale 1:250,000. http://wwwdggs.dnr.state.ak.us/scan1/aof/text/AOF003.PDF (135 KB) http://wwwdggs.dnr.state.ak.us/scan1/aof/oversized/AOF003-SH1.SID (2181 KB)

Alaska Geologic Survey, 1973, Aeromagnetic map, northern Solomon Quadrangle: Alaska Division of Geological \& Geophysical Surveys AOF 6, 5 p., 1 sheet, scale 1:250,000. http://wwwdggs.dnr.state.ak.us/scan1/aof/text/AOF006.PDF (143 KB) http://wwwdggs.dnr.state.ak.us/scan1/aof/oversized/AOF006-SH1.SID (1674 KB)

Alaska Division of Geologic \& Geophysical Surveys, Dighem, W.G.M., 1994, Total field magnetics of the Nome mining district: Alaska Division of Geological \& Geophysical Surveys, Report of Investigation 94-10. http://wwwdggs.dnr.state.ak.us/scan1/ri/oversized/RI94-10-SH1.SID (16889 KB) 
Alaska Division of Geologic \& Geophysical Surveys, Dighem, W.G.M., 1994, Color shadow total field magnetics of the Nome mining district: Alaska Division of Geological \& Geophysical Surveys, Report of Investigation 94-11. http://wwwdggs.dnr.state.ak.us/scan1/ri/oversized/RI94-11-SH1.SID (5065 KB)

Alaska Division of Geologic \& Geophysical Surveys, Dighem, W.G.M., 1994, 7200 Hz Coplanar resistivity of the Nome mining district: Alaska Division of Geological \& Geophysical Surveys, Report of Investigation 9412.

http://wwwdggs.dnr.state.ak.us/scan1/ri/oversized/RI94-12-SH1.SID (4443 KB)

Alaska Division of Geologic \& Geophysical Surveys, Dighem, W.G.M., 1994, 900 Hz Coplanar resistivity of the Nome mining district: Alaska Division of Geological \& Geophysical Surveys, Report of Investigation 9413. http://wwwdggs.dnr.state.ak.us/scan1/ri/oversized/RI94-13-SH1.SID (4381 KB)

Alaska Division of Geologic \& Geophysical Surveys, Dighem, W.G.M., 1994, CD-ROM digital archive files of 1993 survey data for Nome, Circle, Nyac, and Valdez Creek mining districts: Alaska Division of Geological \& Geophysical Surveys, Public Data File 94-15. http://wwwdggs.dnr.state.ak.us/scan2/pdf94/text/PDF94-15.PDF (359 KB)

Alaska Division of Geologic \& Geophysical Surveys, Dighem, W.G.M., 1994, Final summary of 1993 airborne geophysical surveys of the Nome, Circle, Nyac, and Valdez Creek areas: Alaska Division of Geological \& Geophysical Surveys, Public Data File 94-36, 327 p., 4 sheets. http://wwwdggs.dnr.state.ak.us/scan2/pdf94/text/PDF94-36.PDF (10191 KB) http://wwwdggs.dnr.state.ak.us/scan2/pdf94/oversized/PDF94-36-SH2.SID (3521 KB) http://wwwdggs.dnr.state.ak.us/scan2/pdf94/oversized/PDF94-36-SH2.SID (2826 KB) http://wwwdggs.dnr.state.ak.us/scan2/pdf94/oversized/PDF94-36-SH2.SID (1586 KB)

Alaska Division of Geologic \& Geophysical Surveys, Dighem, W.G.M., 1994, Total field magnetics and electromagnetic anomalies of the Nome mining district: Alaska Division of Geological \& Geophysical Surveys, Report of Investigation 94-01. http://wwwdggs.dnr.state.ak.us/scan1/ri/oversized/RI94-01$\underline{\text { SH1.SID }}(13051 \mathrm{~KB})$

Cady and others, 1977, Aeromagnetic interpretation map of Seward Peninsula, Alaska: U.S. Geological Survey Open-File Report 77-796G, 1 sheet, scale 1:1,000,000.

Decker, John, and Karl, Susan, 1977, Aeromagnetic profiles of Seward Peninsula: U.S. Geological Survey OpenFile Report 77-796F, 1 sheet, scale 1:1,000,000.

Decker, John, and Karl, Susan, 1977, Preliminary aeromagnetic map of Seward Peninsula: U.S. Geological Survey Open-File Report 77-796E, 1 sheet, scale 1:1,000,000.

Johnson, G.R., and Sainsbury, C.L., 1974, Aeromagnetic and generalized geologic map of the west-central part of the Seward Peninsula, Alaska: U.S. Geological Survey GP-881, scale 1:125,000

Saltus, R.W., and Simmons, G.C., 1997, Composite and merged aeromagnetic data for Alaska: A website for distribution of gridded data and plot files: U.S. Geological Survey Open-File Report OFR 97-520. http://greenwood.cr.usgs.gov/pub/open-file-reports/ofr-97-0520/alaskamag.html

Texas Instruments, Inc., 1975, Airborne geophysical survey - Copper River and Seward-Selawik areas, Alaska: U.S. Energy Research and Development Administration report GJO-1653, scale 1:500,000.

U.S. Geological Survey,1969, Airborne geophysical surveys in Seward Peninsula area, Alaska: U.S. Geological Survey Open-File Report 69-294 (old numbering system = 380), scale 1:63,360.

\section{GEOLOGIC DATA}

Asher, R.R., 1969, Geological and geochemical study, Solomon C-5 Quadrangle, Seward Peninsula, Alaska: Alaska Division of Geological \& Geophysical Surveys, Geologic Report 33, 64 p., 2 sheets. http://wwwdggs.dnr.state.ak.us/scan1/gr/text/GR33.PDF (1470 KB) http://wwwdggs.dnr.state.ak.us/scan1/gr/oversized/GR33-SH01.SID (3853 KB) http://wwwdggs.dnr.state.ak.us/scan1/gr/oversized/GR33-SH01.SID (2985 KB)

Bundtzen, T.K., Reger, R.D., Laird, G.M., Pinney, D.S., Clautice, K.H., Liss, S.A., Cruse, G.R., 1994, Progress report on the geology and mineral resources of the Nome Mining district: Alaska Division of Geological \& Geophysical Surveys Public Data File 94-39, 21 p., 2 sheets, scale 1:63,360. http://wwwdggs.dnr.state.ak.us/scan2/pdf94/text/PDF94-39.PDF (793 KB) http://wwwdggs.dnr.state.ak.us/scan2/pdf94/oversized/PDF94-39-SH1.SID (7199 KB) http://wwwdggs.dnr.state.ak.us/scan2/pdf94/oversized/PDF94-39-SH1.SID (2105 KB)

Burleson, Judy, 1969, Trend surface analysis of the Solomon Quadrangle and Big Hurrah Mine: Alaska Territorial 
Department of Mines, Miscellaneous Report 53-02, 26 p.

http://wwwdggs.dnr.state.ak.us/scan1/mr/text/MR053-02.PDF

Gamble, B. M., 1988, Non-placer mineral occurrences in the Solomon, Bendeleben, and southern part of the Kotzebue quadrangles, western Alaska: U.S. Geological Survey MF-1838-B, 13 p., 1 sheet, scale $1: 250,000$.

Gamble, B. M., Harris, E. E., Sutley, S. J., and Walker, K. M., 1988, Analytical results and sample locality map for rock samples from the Solomon, Bendeleben, and southern part of the Kotzebue quadrangles, western Alaska, OF 88-0266, 118 p., 1 sheet, scale 1:250,000.

Gamble, B. M., Till, A. B., 1993, Maps showing metallic mineral resources of the Bendeleben and Solomon quadrangles, western Alaska: U.S. Geological Survey MF-1838-D, 22 p., 3 sheets, scale 1:250,000.

Herreid, Gordon, 1965, Geology of the Bluff area, Solomon Quadrangle, Seward Peninsula: Alaska Division of Mines and Minerals, Geologic Report 10, 24 p., 1 sheet. http://wwwdggs.dnr.state.ak.us/scan1/gr/text/GR10.PDF (890 KB) http://wwwdggs.dnr.state.ak.us/scan1/gr/oversized/GR10-SH01.SID (1122 KB)

Hudson, Travis, 1999, The Alaska Resource Data Files, Bendeleben Quadrangle, U.S. Geological Survey Open-File Report 99-332. http://ardf.wr.usgs.gov/quads/html/Bendeleben.html

Hudson, Travis, 1999, The Alaska Resource Data Files, Solomon Quadrangle, U.S. Geological Survey Open-File Report 99-573. http://ardf.wr.usgs.gov/quads/html/Bendeleben.html

Kaufman, D.S., 1986, Surficial geologic map of the Solomon, Bendeleben and southern part of the Kotzebue quadrangles: U.S. Geological Survey Miscellaneous Field Studies Map MF-1838-A, 1 sheet, scale $1: 250,000$.

King, H. D., Smith, S. C., Sutley, S. J., and Greene, K. R., 1989, Geochemical maps showing the distribution and abundance of selected elements in nonmagnetic heavy-mineral-concentrate samples from stream sediment, Solomon and Bendeleben 1 degrees by 3 degrees Quadrangles, Seward Peninsula, Alaska: U.S. Geological Survey MF-2071-B, 13 p., 1 sheet, scale 1:250,000.

King, H. D., Smith, S. C., and Werschky, Scott, 1989, Mineralogical maps showing the distribution and abundance of selected minerals in nonmagnetic heavy-mineral-concentrate samples from stream sediment, Solomon and Bendeleben 1 degrees by 3 degrees Quadrangles, Seward Peninsula, Alaska: U.S. Geological Survey MF-2071-C, 4 p., 1 sheet, scale 1:250,000.

King, H. D., Sutley, S. J., O'Leary, R. M., McDougal, C. M., and Duttweiler, K. A., 1982, Analytical data for minus80-mesh stream-sediment samples collected during 1981 from the Solomon and Bendeleben quadrangles, Alaska: U.S. Geological Survey OF 82-0964, 46 p., 2 sheets, scale 1:250,000.

Robinson, M.S., Stevens, D.L., 1984, Geologic map of the Seward Peninsula: Alaska Division of Geological \& Geophysical Surveys, Special Report 34, 1 sheet, scale 1:500,000. http://wwwdggs.dnr.state.ak.us/scan1/sr/oversized/SR34-SH1.SID (11146 KB)

Sainsbury, C.L., Hudson, Travis, Ewing, Rodney, and Marsh, W.R., 1972a Reconnaissance geologic map of the Solomon D-5 and C-5 quadrangles, Seward Peninsula, Alaska: U.S. Geological Survey Open-File Report 72-323, 12 p., 1 sheet, scale 1:63,360.

Sainsbury, C.L., Hudson, Travis, Ewing, Rodney, and Marsh, W.R., 1972b Reconnaissance geologic map of the west half of the Solomon quadrangle, Alaska: U.S. Geological Survey Open-File Report 72-324, 10 p., 1 sheet, scale 1:63,360.

Smith, S. C., King, H. D., O'Leary, R. M., 1989, Geochemical maps showing the distribution and abundance of selected elements in stream-sediment samples, Solomon and Bendeleben 1 degrees by 3 degrees Quadrangles, Seward Peninsula, Alaska: U.S. Geological Survey MF-2071-A, 13 p. 13, 1 sheet, scale 1:250,000.

Szumigala, D.J., 1999, Map of prospective mineral areas and significant mineral resources of Alaska: Alaska Division of Geological \& Geophysical Surveys Miscellaneous Publication 38, 1 sheet, scale 1:2,500,000.

Szumigala, D.J., and Swainbank, R.C., 1998, Map of selected mines, coalfields, and significant mineral resources of Alaska: Alaska Division of Geological \& Geophysical Surveys Miscellaneous Publication 33, 1 sheet, scale 1:250,000.

Till, A.B., Dumoulin, J.A., Gamble, B.M., Kaufman, D.S., and Carroll, P.I., 1986, Preliminary geologic map and fossil data, Solomon, Bendeleben, and southern Kotzebue quadrangles, Seward Peninsula, Alaska: U.S. Geological Survey Open-File Report 86-276, 69 p., 3 sheets, scale 1:250,000.

Yeend, W.E., Kaufman, D. S., Till, A. B., 1988, Placer gold of the Solomon, Bendeleben, and southern part of the Kotzebue quadrangles, western Alaska: U.S. Geological Survey MF-1838-C, 1 sheet, scale 1:250,000. 


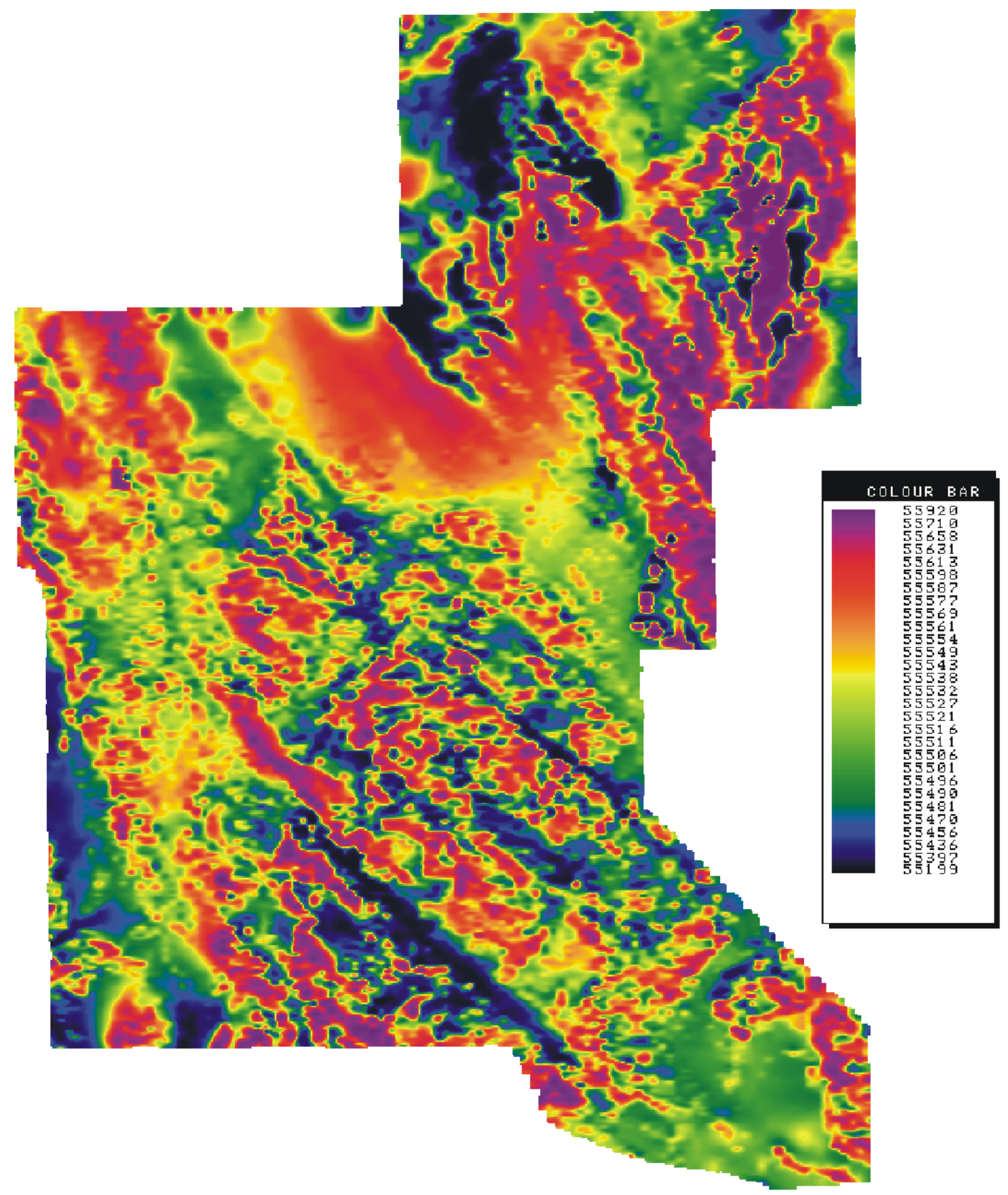

Figure 4a. Total field magnetics of the Council area, Seward Peninsula. Magnetic units are in Nt. Diagram shown with an equal area color scheme. 


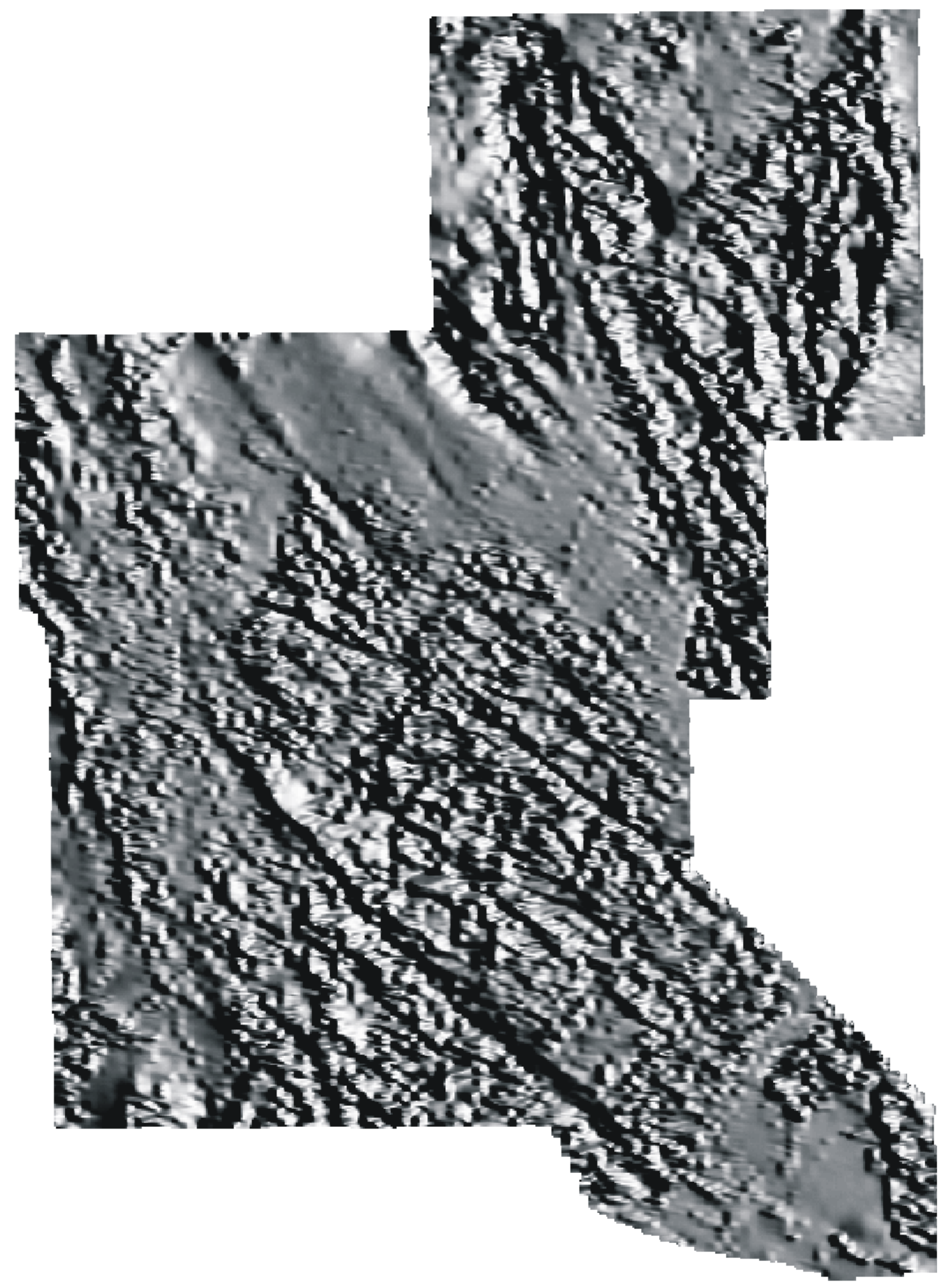

Figure $4 \mathrm{~b}$. Shadow map of the total field magnetics of the Council area, Seward Peninsula. Illuminations from N75E 


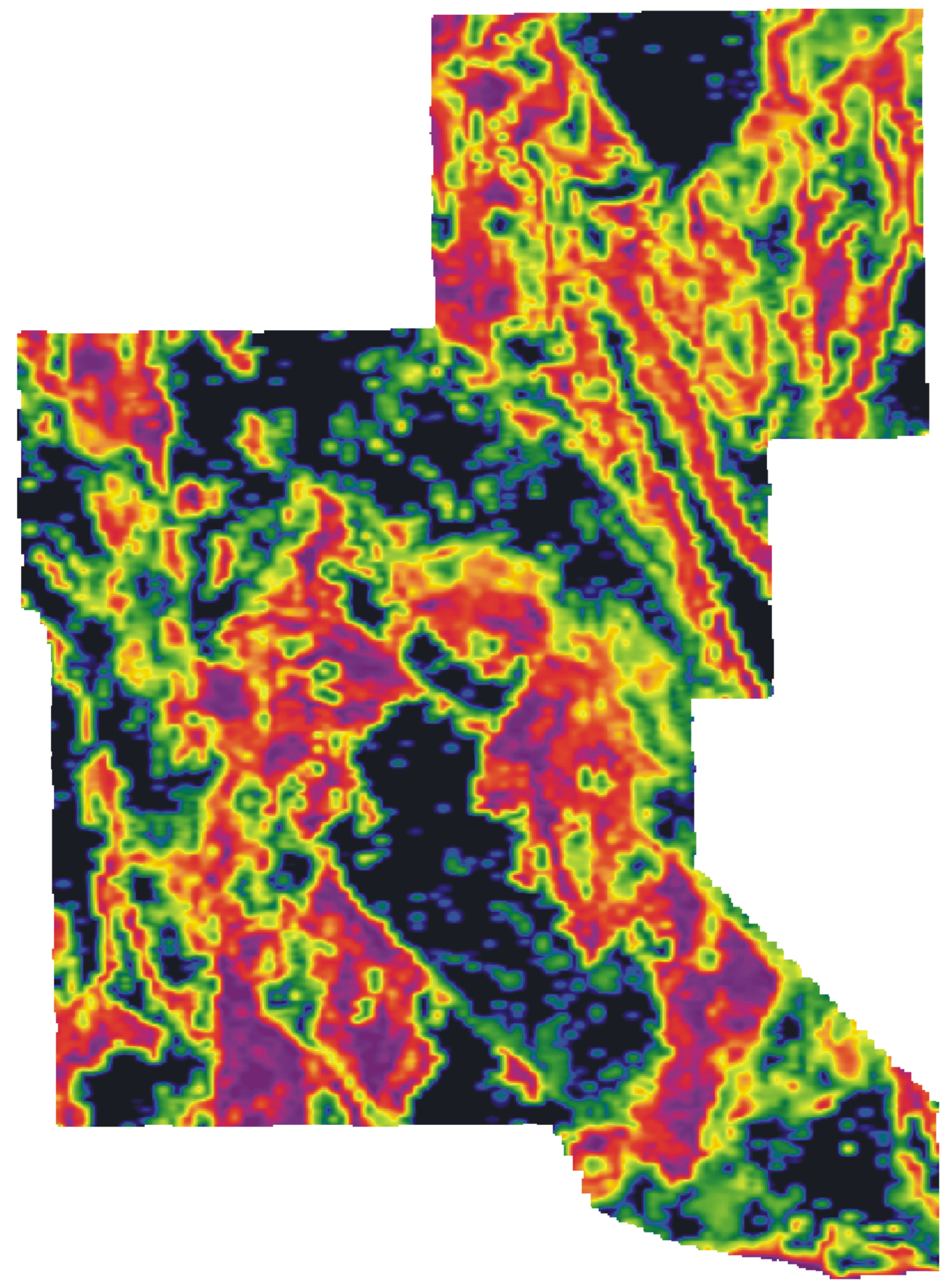

Figure 5. $900 \mathrm{~Hz}$ coplanar resistivity of the Council area, Seward Peninsula. Resistivity units in ohm$\mathrm{m}$. Conductive units have low numbers and are shown in purple and orange on this map. Diagram shown with an equal area color shceme. 


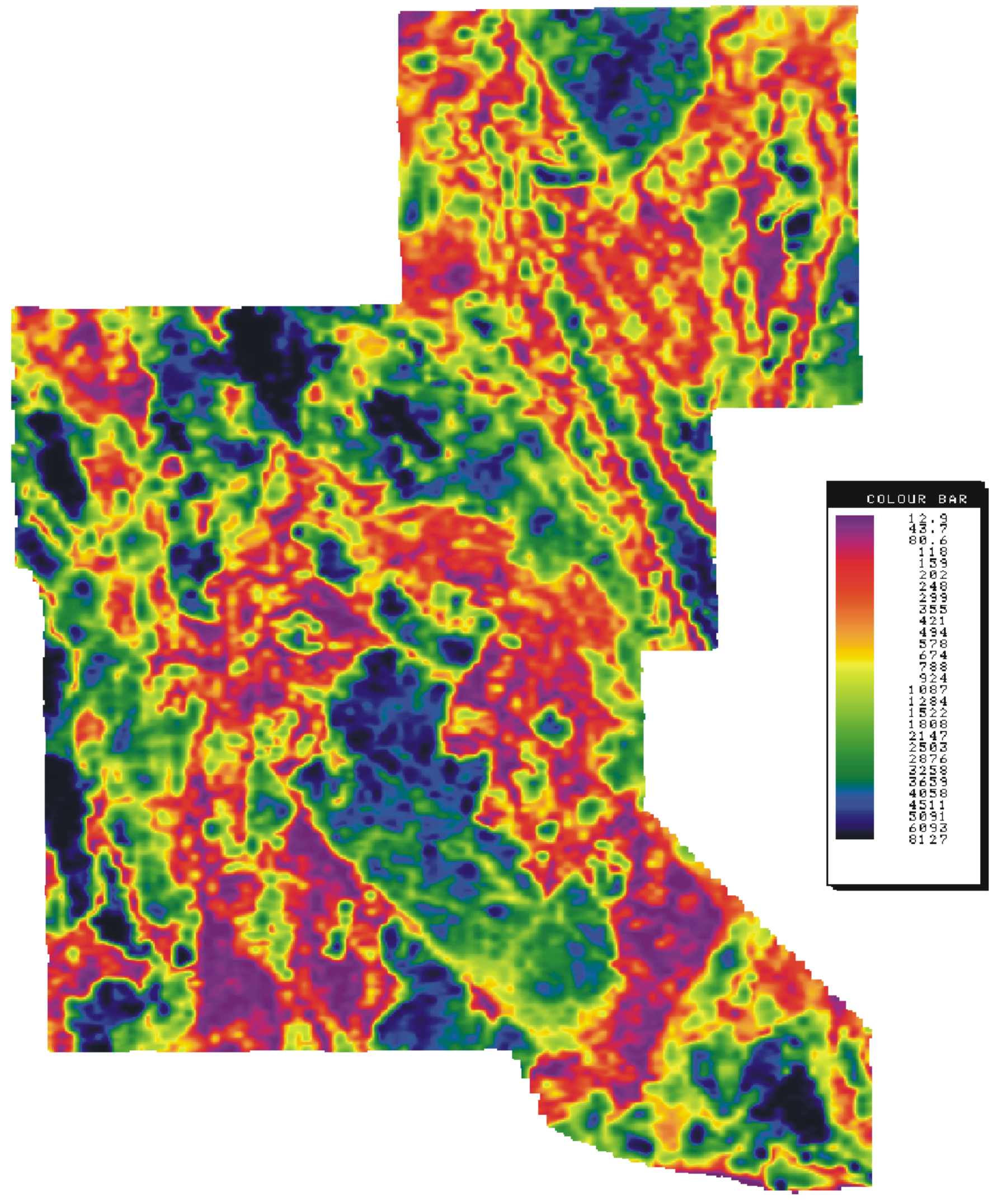

Figure $6.7200 \mathrm{~Hz}$ coplanar resistivity of the Council area, Seward Peninsula. Resistivity units in ohm-m. Conductive units have low numbers and are shown in purple and orange on this map. Diagram shown with an equal area color shceme. 


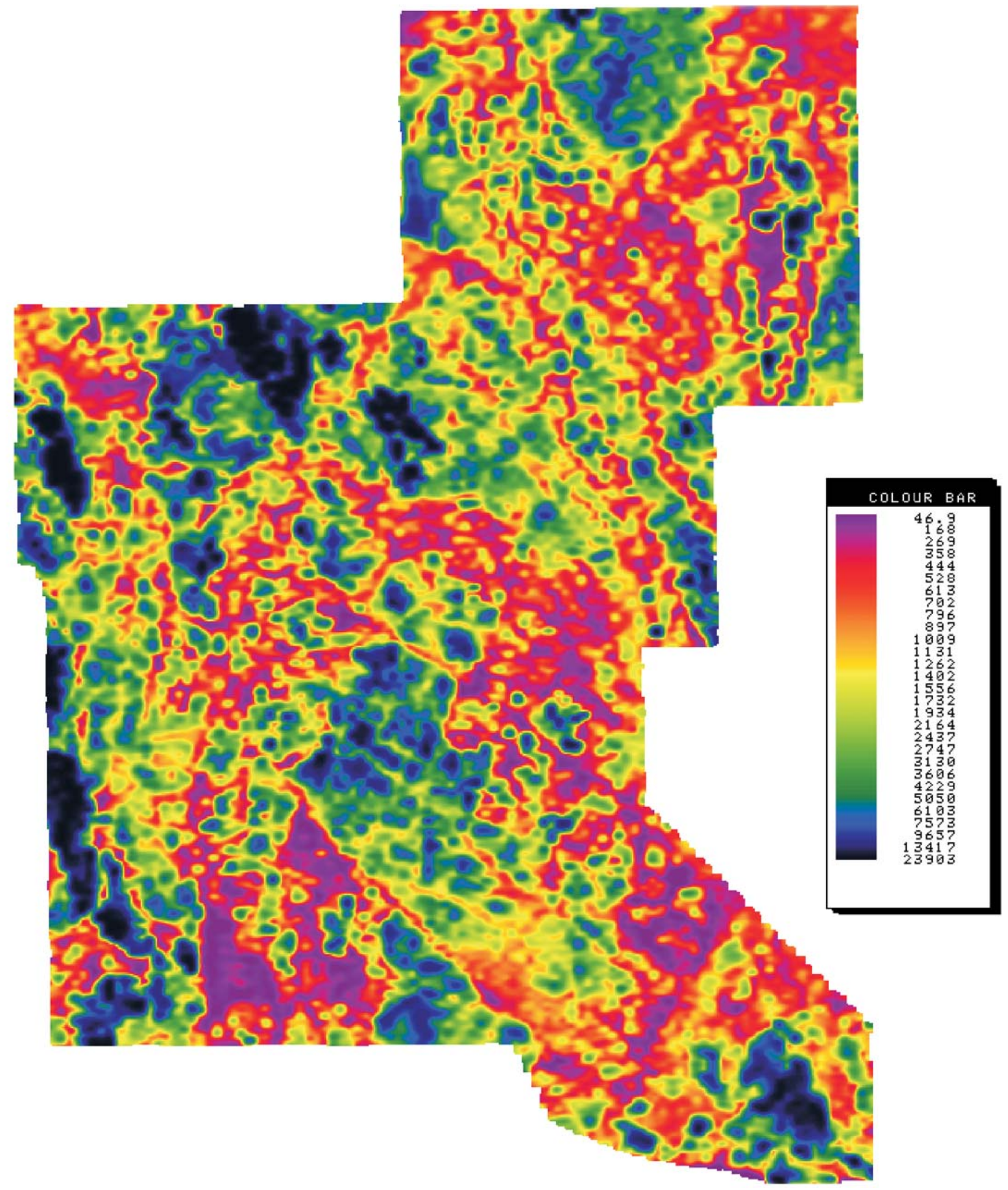

Figure 7. 56,000 Hz coplanar resistivity of the Council area, Seward Peninsula. Resistivity units in ohm-m. Conductive units have low numbers and are shown in purple and orange on this map. Diagram shown with an equal area color scheme. 


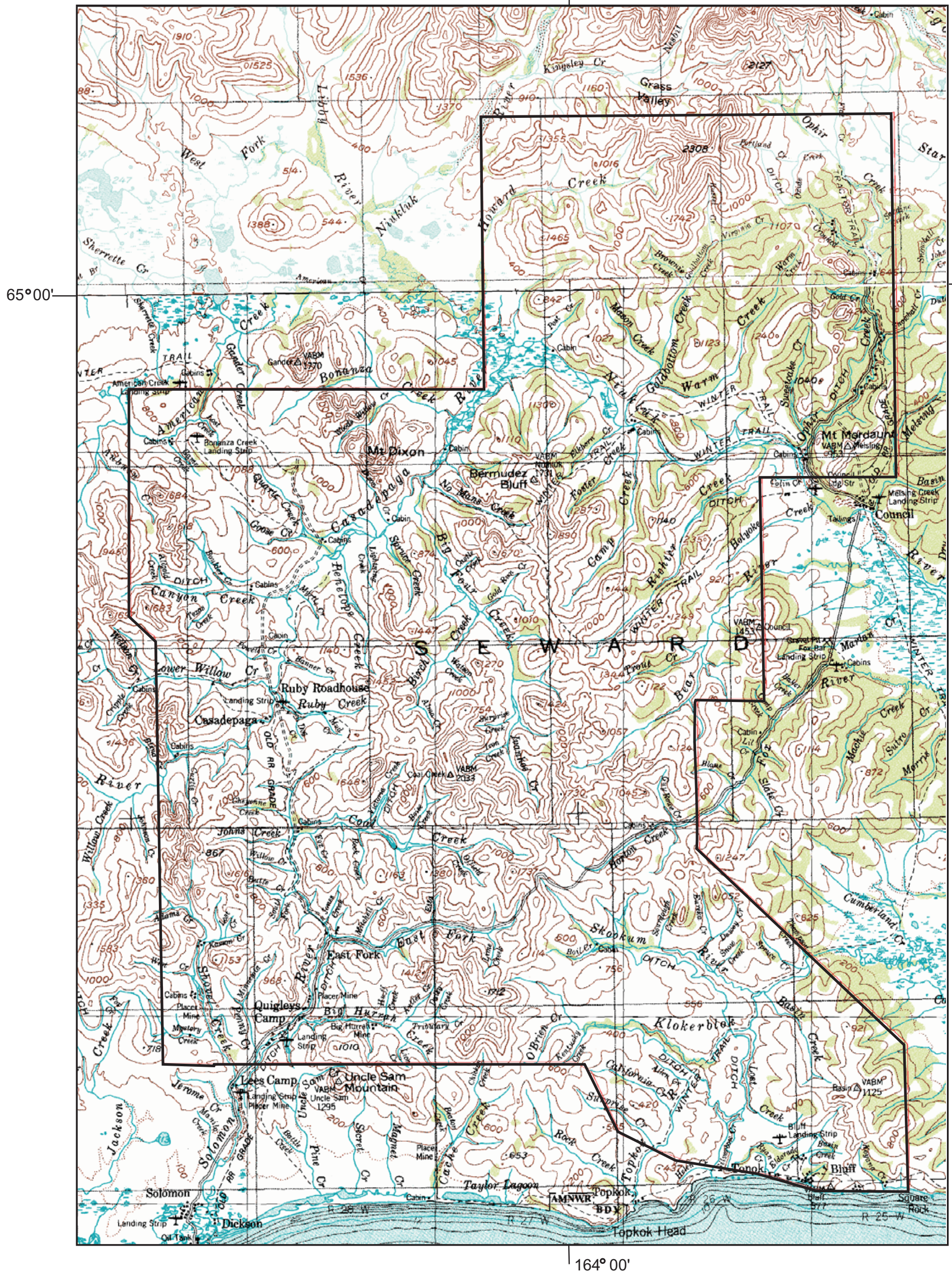

